\title{
PERLINDUNGAN HUKUM BAGI DEBITUR DALAM PERJANJIAN KREDIT DITINJAU DARI UNDANG-UNDANG NOMOR 8 TAHUN 1999 TENTANG PERLINDUNGAN KONSUMEN
}

\author{
Aan Handriani \\ Fakultas Hukum Universitas Pamulang \\ aanhandriani@gmail.com
}

\begin{abstract}
The agreement becomes an instrument to accommodate or bring together different interests between 2 (two) or more parties. A bank credit agreement is a preliminary agreement on handing over money. Banking credit agreements generally use the standard form of agreement, in practice the form of the agreement has been provided by the bank as a creditor while creditors only study and understand it well. Where in the agreement the debtor is only in the position of accepting or rejecting without any possibility to negotiate or bargain, which in the end creates an agreement that is not too favorable for one party. In an agreement like this, the second party (the debtor) is not at all able to submit proposals or input and object to the format of the agreement and the clauses contained therein.
\end{abstract}

\section{Keywords: Credit agreement, Conformity of the credit agreement clause with the Consumer Protection Act.}

\begin{abstract}
ABSTRAK
Perjanjian menjadi instrument untuk mengakomodir atau mempertemukan kepentingan yang berbeda antara 2 (dua) pihak atau lebih. Perjanjian kredit bank adalah perjanjian pendahuluan dari penyerahan uang. Perjanjian kredit perbankan pada umumnya menggunakan bentuk perjanjian baku, dalam prakteknya bentuk perjanjiannya sudah disediakan oleh pihak bank sebagai kreditur sedangkan kreditur hanya mempelajari dan memahaminya dengan baik. Dimana dalam perjanjian tersebut pihak debitur hanya dalam posisi menerima atau menolak tanpa ada kemungkinan untuk melakukan negosiasi atau tawar menawar, yang pada akhirnya melahirkan suatu perjanjian yang tidak terlalu menguntungkan bagi salah satu pihak. Dalam perjanjian seperti ini, pihak kedua (debitur) sama sekali tidak dapat mengajukan usul ataupun masukan dan keberatan terhadap format perjanjian dan klausula-klausula yang ada didalamnya.
\end{abstract}

Kata Kunci: Perjanjian kredit, Kesesuaian klausul perjanjian kredit dengan Undang-Undang Perlindungan Konsumen. 


\section{PENDAHULUAN}

Dengan seiring terus meningkatnya kebutuhan masyarakat di berbagai bidang kehidupan, meningkat pula kebutuhan terhadap pendanaan. Sebagian besar dana yang diperlukan untuk memenuhi kebutuhan tersebut diperoleh melalui kegiatan pinjam meminjam atau perjanjian kredit. Lembaga perbankan adalah salah satu lembaga yang berfungsi untuk menyimpan dan menyalurkan dana kepada masyarakat berupa kredit untuk memenuhi kebutuhannya.

Menurut ketentuan Undang-

Undang No. 10 Tahun 1998 tentang Perbankan tidak mengatur tentang bentuk dari perjanjian kredit bank, namun pasal 1 butir 11 menyebutkan bahwa: "Kredit adalah penyediaan uang atau tagihantagihan yang dapat disamakan dengan itu, berdasarkan persetujuan atau kesepakatan bank dengan pihak lainnya".

Dari ketentuan-ketentuan ini dapat disimpulkan bahwa bentuk dari perjanjian kredit bank diserahkan pada yakni pihak kreditur (bank) dan pihak debitur untuk membuatnya. Berdasarkan UndangUndang No. 10 Tahun 1998 tentang Perbankan terdapat dua hubungan hukum antara bank dengan nasabah, yaitu:

1. Hubungan hukum antara bank dengan nasabah penyimpan dana.

2. Hubungan hukum antara bank dengan nasabah debitur.

Perjanjian menjadi instrument untuk mengakomodir kepentingan yang berbeda antara dua pihak atau lebih. Melalui perjanjian, perbedaan tersebut diakomodasi dan selanjutnya dibingkai dengan perangkat hukum sehingga mengikat para pihak. Dalam kontrak bisnis pertanyaan mengenai sisi kepastian dan keadilan justru akan tercapai apabila perbedaan yang ada di antara para pihak terakomodasi melalui mekanisme hubungan kontraktual yang bekerja secara proposional. (Agus Yudha Hernoko, 2013:31-32).

Berdasarkan Pasal 1338 KUH Perdata dinyatakan bahwa "semua perjanjian yang dibuat secara sah berlaku sebagai undang-undang bagi mereka yang membuatnya". Dalam pasal tersebut menganut asas kebebasan berkontrak, maka para pihak dalam perjanjian pembiayaan konsumen dapat membuat suatu perjanjian sesuai dengan kehendak para pihak. Asas kebebasan berkontrak atau freedom of contract merupakan adanya kebebasan seluas-luasnya yang oleh undang-undang diberikan kepada masyarakat untuk mengadakan perjanjian tentang apa saja, asalkan tidak bertentangan dengan peraturan perundang-undangan, kepatutan dan ketertiban umum.(Johanne Daeng Naja, 2009:261-263)

Suatu perjanjian menjadi sah apabila telah memenuhi syarat-syarat yang ditentukan oleh Undang-Undang. Syarat sahnya perjanjian diatur dalam pasal 1320 KUHPerdata, antara lain :

a. Adanya kata sepakat mereka yang mengikatkan diri.

Kata sepakat berarti adanya titik temu diantara para pihak tentang kepentingan-kepentingan para pihak. Kesepakatan mengandung pengertian bahwa para pihak saling menyatakan kehendak masing-masing untuk menutup sebuah perjanjian dengan pernyataan salah satu pihak "cocok" dengan pernyataan pihak yang lain. (Kartini Muljadi dan Gunawan Widjaja, 2003:46)

b. Kecakapan untuk membuat suatu perjanjian.

Kecakapan untuk membuat suatu perjanjian adalah kewenangan untuk melakukan perbuatan-perbuatan hukum sendiri. Para pihak yang membuat perjanjian apabila orangperorangan harus sudah dewasa, sehat akal-fikir, dan tidak di bawah perwalian/pengampuan. Apabila yang melakukan perjanjian adalah suatu badan hukum atau organisasi, maka harus orang yang mempunyai kewengangan atau kompeten untuk melakukan hubungan hukum dengan pihak lain.

c. Suatu hal tertentu.

Hal tertentu artinya adalah objek perjanjian itu sendiri, yaitu apa yang 
diperjanjikan. Hak-hak dan kewajiban yang timbul dari perjanjian itu harus jelas disebutkan di dalamnya. Pasal 1333 KUH Perdata menyebutkan bahwa :"Suatu perjanjian harus mempunyai sebagai pokok suatu barang yang paling sedikit ditentukan jenisnya. Tidaklah menjadi halangan bahwa jumlah barang tidak tentu, asal saja jumlah itu terkemudian dapat ditentukan atau dihitung".

d. Suatu sebab yang halal.

Sebab adalah yang menyebabkan orang membuat perjanjian, yang mendorong orang membuat perjanjian. Suatu sebab yang halal berarti obyek yang diperjanjikan bukanlah obyek yang terlarang tapi diperbolehkan oleh hukum. Suatu sebab yang tidak halal itu meliputi perbuatan melanggar hukum, berlawanan dengan kesusilaan dan melanggar ketertiban umum. Perjanjian kredit bank antara pihak bank dengan pihak debitur harus memenuhi syarat-syarat perjanjian sebagaimana tercantum dalam pasal 1320 KUHPerdata tersebut di atas.

Berdasarkan Undang-Undang

Nomor 8 Tahun 1999 tentang Perlindungan Konsumen (UUPK), telah diatur larangan pencantuman klausula baku pada setiap dokumen dan/atau perjanjian apabila berisi tentang pengalihan tanggung jawab pelaku usaha (Pasal 18), akan tetapi dalam kenyataannya masih sering dijumpai. Dengan alasan memperhatikan kebiasaan yang berlaku di lingkungan perbankan tersebut dan adanya kebutuhan akan perbankan di masyarakat namun awamnya pengetahuan masyarakat terkait keberadaan klausula baku yang terdapat dalam setiap transaksi perbankan.

Dalam hukum perjanjian terdapat beberapa asas penting yang menjadi dasar dalam pelaksanaan perjanjian. Sama halnya dalam perjanjian kredit, asas-asas ini merupakan pedoman dan dasar kehendak masing-masing pihak dalam mencapai tujuannya. Terdapat 5 asas dalam membuat perjanjian, yaitu, (Johannes Ibrahim dan Lindawaty Sewu, 2004:99) :

1. Asas Pacta Sunt Servada.
Pasal 1338 ayat (1) KUHPerdata , yang menyatakan bahwa semua perjanjian yang dibuat secara sah berlaku sebagai undang-undang bagi mereka yang membuatnya. Artinya bahwa mereka belah pihak wajib mentaati dan melaksaakan perjanjian yang telah disepakati sebagaimana mentaati undang-undang. Oleh karena itu, akibat dari asas pacta sunt servada adalah perjanjian tiak dapat ditarik kembali tanpa persetujuan dari pihak lain. Hal ini disebutkan dalam pasal 1338 ayat (2) KUHPerdata yaitu suatu perjanjian tidak dapat ditarik kembali selain dengan sepakat dua belah pihak, atau karena alasan-alasan yang oleh undang-undang dinyatakan cukup untuk itu.

2. Asas Konsensualisme.

Asas konsensualisme mempunyai arti yang terpenting, yaitu bahwa untuk melahirkan perjanjian adalah cukup dengan dicapainya suatusyarat-syarat yang telah ditentukan dalam Pasal 1320 KUHPerdata dan bahwa perjanjian tersebut telah dilahirkan pada saat telah tercapainya suatu kesepakatan antara para pihak yang terlibat dalam perjanjian tersebut. Dengan begitu, suatu perjanjian telah sah ketika syarat-syarat yang ada dalamPasal 1320 KUHPerdata tersebut telah dipenuhi dan lahir ketika para pihak telah mengucapkan kata sepakat.

3. Asas Itikad Baik.

Dalam KUHPerdata pada Pasal 1338 ayat (3) menyatakan bahwa : "perjanjian itu harus dilakukan dengan itikad baik". Dengan kata lain, setiap orang atau badan hukum (subyek hukum) yang ingin mengadakan perjanjian harus mempunyai itikatbaik. Itikad baik di sini merupakan suatu bentuk perlindungan untuk memberikan perlindungan hukum bagi salah satu pihak yang mempunyai itikad baik dalam perjanjian baik dalam waktu pembuatan perjanjian maupun pada waktu pelaksanaan perjanjian.

4. Asas Kepribadian.

Asas ini berhubungan dengan subyek yang terikat dalam suatu perjanjian. Asas kepribadian dalam 
KUHPerdata diatur dalam pasal 1340 ayat (1) yang menyatakan bahwa suatu perjanjian hanya berlaku antara pihak yang membuatnya. Pernyataan ini mengandung arti bahwa perjanjian yang dibuat oleh para pihak hanya berlaku bagi mereka yang membuatnya. Ketentuan mengenai hal ini ada pengecualiannya, sebagaimana yang diatur dalam pasal 1337 KUHPerdata yaitu, dapat pula perjanjia diadakan untuk kepentingan pihak ketiga, bila suatu perjanjian dibuat untuk diri sendiri, atau suatu pemberian kepada orang lain, mengandung suatu syarat semacam itu.

5. Asas Kebebasan Berkontrak.

Hal ini menjelaskan bahwa, setiap subyek hukum mempunyai kebebasan dalam mengadakan suatu bentuk perjanjian apa saja maupun perjanjian yang telah diatur dalam undangundang. Perbuatan ini mengasumsikan bahwa adanya suatu kebebasan tertentu di dalam masyarakat untuk dapat turut serta di dalam lalu lintas yuridis. Dengan kata lain, kebebasan berkontrak adalah begitu esensial, baik bagi individu untuk mengembangkan diri di dalam kehidupan pribadi dan didalam lalulintas kemasyarakatan serta untuk mengindahkan kepentingan-kepentingan harta kekayaannya.

\section{METODE PENELITIAN}

Jenis penelitian yang dilakukan ini adalah jenis penelitian hukum normatif. Penelitian hukum normatif menurut Soerjono Soekanto adalah sebagai penelitian hukum kepustakaan yang mencakup penelitian terhadap asas-asas hukum, sistem hukum, penelitian taraf sinkronisasi vertikal dan horizontal, perbandingan hukum serta sejarah hukum. (Soerjono Soekanto, 2007:17).

Jenis pendekatan masalah yang digunakan dalam penulisan ini adalah pendekatan perundang-undangan (Statute Approach), yaitu dengan menelaah semua Undang-Undang yang berkaitan dengan isu hukum yang sedang ditangani. Sumber bahan hukum yang digunakan dalam penelitian ini adalah bahan hukum primer yang berupa peraturan perundangan yang berkaitan dengan masalah yang dibahas, bahan hukum sekunder yang berupa rancangan peraturan perundangan, surat kabar dan bahan hukum tersier seperti kamus. Teknik pengumpulan bahan hukum yang digunakan dalam penelitian ini adalah dengan melakukan studi pustaka terhadap bahan hukum, serta penelusuran bahan-bahan hukum.

\section{PERMASALAHAN}

Adapun permasalahan yang diangkat dalam penelitian ini adalah: pertama bagaimana akibat hukum perjanjian baku bagi debitur dalam pelaksanaan perjanjian kredit perbankan? kedua bagaimana perlindungan hukum bagi debitur dalam pelaksanaan perjanjian kredit perbankan ditinjau dari Undang-Undang No. 8 Tahun 1999 Tentang Perlindungan Konsumen?

\section{PEMBAHASAN}

\section{Akibat Hukum Perjanjian Baku Bagi Debitur Dalam Pelaksanaan Perjanjian Kredit Perbankan}

Perjanjian itu terjadi, karena adanya suatu kata sepakat atau persesuaian (pernyataan) kehendak, kata sepakat itu terjadi, karena pihak yang satu menyampaikan penawaran kepada pihak lain kalau setuju menyampaikan penerimaan kepada pihak yang satunya. Jadi pada hakekatnya yang terjadi merupakan persesuaian pernyataan kehendak sebab kehendak tidak akan sampai pada pihak lain kalau tidak dinyatakan atau disampaikan. Dengan demikian ada dua perbuatan yang masingmasing bersifat satu sisi yaitu penawaran di satu pihak dan penerimaan di pihak lain.

Pencantuman klausul baku dalam hal hubungan pelaku usaha dan konsumen harus memperhatikan ketentuan Pasal 18 Undang-Undang Perlindungan Konsumen yang dinyatakan bahwa :

1. Pelaku usaha dalam menawarkan barang dan/atau jasa yang ditujukan untuk diperdagangkan dilarang membuat atau mencantumkan klausula baku pada setiap dokumen dan/atau perjanjian apabila: 
a. Menyatakan pengalihan tanggung jawab pelaku usaha;

b. Menyatakan bahwa pelaku usaha berhak menolak penyerahan kembali uang yang dibeli konsumen;

c. Menyatakan bahwa pelaku usaha berhak menolak penyerahan kembali uang yang dibayarkan atas barang dan/atau jasa yang dibeli oleh konsumen;

d. Menyatakan pemberian kuasa dari komsumen kepada pelaku usaha baik secara langsung maupun tidak langsung untuk melakukan segala tindakan sepihak berkaitan dengan barang yang dibeli oleh konsumen secara angsuran;

e. Mengatur perihal pembuktian atas hilangnya kegunaan barang atau pemanfaatan jasa yang dibeli oleh konsumen;

f. Memberi hak kepada pelaku usaha untuk mengurangi manfaan jasa atau mengurangi harta kekayaan konsumen yang menjadi objek jual beli jasa;

g. Menyatakan tunduknya konsumen kepada peraturan yang berupa aturan baru, tambahan lanjutan dan/atau pengubahan lanjutan yang dibuat sepihak oleh pelaku usaha dalam masa konsumen memanfaatkan jasa yang dibelinya;

h. Menyatakan bahwa konsumen memberi kuasa kepada pelaku usaha untuk pembebanan hak tanggungan, hak gadai, atau hak jaminan terhadap barang yang dibeli oleh konsumen secara angsuran;

2. Pelaku usaha dilarang mencantumkan klausul baku yang letak atau bentuknya sulit terlihat atau tidak dapat dibaca secara jelas, atau yang pengungkapannya sulit dimengerti.

3. Setiap klausul baku yang telah ditetapkan oleh pelaku usaha pada dokumen atau perjanjian yang memenuhi ketentuan sebagaimana dimaksud pada ayat (1) dan ayat (2) dinyatakan batal demi hukum.

4. Pelaku usaha wajib menyesuaikan klausula baku yang bertentangan dengan undang-undang ini.

$$
\text { Peranan Undang-Undang }
$$

Perlindungan Konsumen dalam ketentuan yang terdapat pada Pasal 18 yang dimaksud sangat berkaitan erat dan sering terjadi dalam perjanjian kredit/pembiayaan yang diberikan oleh bank adalah ketentuan pada ayat (1) huruf (g), yakni bahwa bank menyatakan tunduknya konsumen kepada peraturan yang berupa aturan baru, tambahan, lanjutan dan/atau pengubahan lanjutan yang dibuat secara sepihak oleh pelaku usaha dalam masa konsumen memanfaatkan jasa yang di belinya. (Prihatin Effendi, 2015:91)

Ketentuan Pasal 18 Undang-Undang Perlindungan Konsumen diatas, larangan penggunaan standar kontrak dikaitkan dengan dua hal, yaitu isi dan bentuk penulisannya. Dari segi isinya, dilarang menggunakan standar kontrak yang memual klausul-klausul yang tidak adil, sedangkan dari segi bentuk penulisannya, klausul-klausul itu harus dituliskan dengan sederhana, jelas, dan terang sehingga dapat dibaca dan dimengerti dengan baik oleh konsumen. (Janus Sidabalok, 2006:27)

Pasal 18 ayat (2) Undang-Undang Perlindungan Konsumen, dijelaskan bahwa pelaku usaha dilarang mencantumkan klausul baku yang letak atau bentuknya sulit terlihat atau tidak dapat dibaca secara jelas, atau yang kengungkapannya sulit dimengerti. Sebagai konsekuensi atas pelanggaran terhadap ketentuan Pasal 8 ayat (1) dan ayat (2) tersebut, Pasal 18 ayat 3 UndangUndang Perlindungan Konsumen dinyatakan batal demi hukum setiap klausula baku yang telah ditetapkan oleh pelaku usaha pada dokumen atau perjanjian yang memuat ketentuan yang dilarang dalam Pasal 18 ayat (1) maupun perjanjian baku atau klasul baku yang memenuhi ketentuan sebagaimana dimaksud pada Pasal 18 ayat (2), hal ini merupakan penegasan kembali akan sifat kebebasan berkontrak yang diatur pada Pasal 1320 KUHPerdata jo Pasal 1338, Pasal 1337 KUHPerdata.

Ini berarti perjanjian yang memuat ketentuan mengenai klausul baku yang dilarang dalam Pasal 18 ayat (1) UndangUndang Perlindungan Konsumen atau yang memiliki format sebagaimana dilarang pada Pasal 13 ayat (2) dianggap 
tidak pemah ada dan mengikat para pihak, pelaku usaha, dan konsumen yang melaksanakan transaksi perdagangan barang dan/atau jasa tersebut. (Made Suryana dan Rina Suwasti, 2009:25)

Penggunaan klausul baku dalam perjanjian sifatnya merupakan memaksa, dalam hal ini memaksa debitur untuk menyetujui isi perjanjiannya. Ketika debitur hendak transaksi, yang banyak terjadi ketika negosiasi dilakukan kreditur menyodori blanko/formulir perjanjian kepada debitur. Biasanya debitur tidak diberi waktu yang cukup untuk mempelajari perjanjian tersebut, melainkan debitur diminta untuk memperlihatkan kartu identitasnya (KTP, SIM, NPWP dan lain sebagainya) kemudian diisikan kedalam perjanjian dan meminta debitur untuk menandatangani blanko/formulir perjanjian tersebut. (Supramono, Gatot, 2009:22)

Akibat kedudukan para pihak yang tidak seimbang, maka pihak lemah biasanya tidak berada dalam keadaan yang betul-betul bebas untuk menuntukan apa yang diinginkannya dalam perjanjian. Dengan demikian, pihak yang memmiliki posisi yang lebih kuat biasanya menggunakan kesempatan tersebut untuk menentukan klausul-klausul tertentu dalam perjanjian baku. Sehingga perjanjian yang seharusnya dibuat oleh para pihak yang terlibat dalam perjanjian tidak ditemukan lagi dalam bentuk perjanjian baku, karena format dan isi perjanjian telah dirancang oleh pihak yang kedudukannya lebih kuat. (Zulham, 2013:68)

Akibat hukum merupakan setiap akibat yang terjadi dari setiap perbuatan hukum yang dilakukan oleh subjek hukum terhadap hukum ataupun akibat yang lain yang disebabkan karena kejadian tertentu yang, oleh hukum bersangkutan telah dianggap sebagai akibat hukum. Akibat hukum yang ditimbulkan oleh adanya suatu hubungan hukum. Suatu hubungan hukum yang memberikan hak dan kewajiban yang telah ditentukan oleh undang-undang, sehingga jika dilanggar akan berakibat, bahwa orang yang melanggar itu dapat dituntut di muka pengadilan. (Soedjono Dirdjosisworo, 2013:131-132)
Akibat hukum tersebutlah yang melahirkan hak dan kewajiban bagi pelaku usaha dan konsumen.

Hak konsumen sebagaimana diatur Pasal 4 Undang-Undang Perlindungan Konsumen, antara lain :

1. Hak atas kenyamanan, keamanan, dan keselamatan dalam mengkonsumsi barang dan/atau jasa;

2. Hak untuk memilih barang dan/atau jasa serta mendapatkan barang dan/atau jasa tersebut sesuai dengan nilai tukar dan kondisi serta jaminan yang dijanjikan;

3. Hak atas informasi yang benar, jelas, dan jujur mengenai kondisi dan jaminan barang dan/atau jasa;

4. Hak untuk didengar pendapat dan keluhannya atas barang dan/atau jasa yang digunakan;

5. Hak untuk mendapatkan advokasi, perlindungan, dan upaya penyelesaian sengketa perlindungan konsumen secara patut;

6. Hak untuk mendapatkan pembinaan dan pendidikan konsumen;

7. Hak untuk diperlakukan atau dilayani secara benar dan jujur serta tidak diskriminatif;

8. Hak untuk mendapatkan kompensasi, ganti rugi dan/atau penggantian, apabila barang dan/atau jasa yang diterima tidak sesuai dengan perjanjian atau tidak sebagaimana mestinya;

9. Hak-hak yang diatur dalam ketentuan peraturan perundang-undangan lainnya.

Kewajiban konsumen diatur dalam Pasal 5 Undang-Undang Perlindungan Konsumen, antara lain:

1. Membaca atau mengikuti petunjuk informasi dan prosedur pemakaian atau pemanfaatan barang dan/atau jasa, demi keamanan dan keselamatan;

2. Beritikad baik dalam melakukan transaksi pembelian barang dan/atau jasa;

3. Membayar sesuai dengan nilai tukar yang disepakati;

4. Mengikuti upaya penyelesaian hukum sengketa perlindungan konsumen secara patut.

Pasal 6 UU Nomor 8 tahun 1999 menyatakan hak pelaku usaha, yaitu : 
1. Hak untuk menerima pembayaran yang sesuai dengan kesepakatan mengenai kondisi dan nilai tukar barang dan/atau jasa yang diperdagangkan;

2. Hak untuk mendapat perlindungan hukum dari tindakan konsumen yang beritikad tidak baik;

3. Hak untuk melakukan pembelaan diri sepatutnya di dalam penyelesaian hukum sengketa konsumen;

4. Hak untuk rehabilitasi nama baik apabila terbukti secara hukum bahwa kerugian konsumen tidak diakibatkan oleh barang dan/atau jasa yang diperdagangkan;

5. Hak-hak yang diatur dalam ketentuan peraturan perundangundangan lainya.

Adapun dalam Pasal 7 Undang-

Undang Perlindungan Konsumen diatur kewajiban pelaku usaha, antara lain:

1. Beritikad baik dalam melakukan kegiatan usahanya;

2. Memberikan informasi yang benar, jelas dan jujur mengenai kondisi dan jaminan barang dan/atau jasa serta memberi penjelasan penggunaan, perbaikan dan pemeliharaan;

3. Memperlakukan atau melayani konsumen secara benar dan jujur serta tidak diskriminatif;

4. Menjamin mutu barang dan/atau jasa yang diproduksi dan/atau diperdagangkan berdasarkan ketentuan standar mutu barang dan/atau jasa yang berlaku;

5. Memberi kesempatan kepada konsumen untuk menguji, dan/atau mencoba barang dan/atau jasa tertentu serta memberi jaminan dan/atau garansi atas barang yang dibuat dan/atau yang diperdagangkan;

6. Memberi kompensasi, ganti rugi dan/atau penggantian atas kerugian akibat penggunaan, pemakaian dan pemanfaatan barang dan/atau jasa yang diperdagangkan;

7. Memberi kompensasi, ganti rugi dan/atau penggantian apabila barang dan/atau jasa yang dterima atau dimanfaatkan tidak sesuai dengan perjanjian.

Akibat hukum perjanjian baku bagi debitur dalam pelaksanaan perjanjian kredit harus tunduk pada syarat-syarat dan ketentuan-ketentuan dalam perjanjian yang telah dibakukan sepihak oleh kreditur tanpa adanya kesepakatan diantara para pihak mengenai kredit dan aturan-aturan kreditnya.

Menurut hukum suatu perjanjian merupakan suatu bentuk manifestasi yang adanya kepastian hukum, oleh karena itu dalam praktiknya setiap perjanjian dibuat secara tertulis agar diperoleh suatu kekuatan kepastian hukum, sehingga tujuan kepastian hukum dapat terwujud. Dalam Kitab Undang-Undang Hukum Perdata (selanjutnya disebut KUHPerdata), ditentukan dan diberikan pengertian mendasar mengenai sebuah perjanjian sebagaimana ditentukan dalam Pasal 1313 KUHPerdata memberikan pengertian "Suatu perjanjian merupakan suatu perbuatan dengan mana satu orang atau lebih mengikatkan dirinya terhadap satu orang atau lebih"(Muhammad Abdulkadir, 2010).

Akibat hukum terhadap klausula baku dalam perjanjian kredit bank yang tidak memenuhi ketentuan Pasal 18 ayat (1) huruf g Undang-Undang Perlindungan Konsumen adalah batal demi hukum. Seperti diatur pada Pasal 18 ayat (3) Undang-Undang Perlindungan Konsumen yang menyatakan bahwa setiap klausul baku yang telah ditetapkan oleh pelaku usaha pada dokumen atau perjanjian yang memenuhi ketentuan sebagaimana dimaksud pada ayat (1) dan (2) Pasal 18 Undang-Undang Perlindungan Konsumen dinyatakan batal demi hukum.

Dalam hal tersebut menunjukkan bahwa perjanjian baku bertentangan baik dengan asas-asas hukum perjanjian (Pasal 1320 jo Pasal 1338 KUHPerdata) maupun kesusilaan. Akan tetapi di dalam praktek, perjanjian ini tumbuh karena keadaan menghendakinya dan harus diterima sebagai kenyataan.

\section{Perlindungan Hukum Bagi Debitur Dalam Pelaksanaan Perjanjian Kredit Perbankan Ditinjau Dari Undang-Undang No. 8 Tahun 1999 Tentang Perlindungan Konsumen \\ Perlindungan hukum adalah} memberikan pengayoman terhadap hak asasi manusia yang dirugikan orang lain dan perlindungan tersebut diberikan kepada masyarakat agar mereka dapat 
menikmati semua hak-hak yang diberikan oleh hukum. (Minatul Lusfida, 2008:21)

Terdapat 2 (dua) bentuk perlindungan hukum, yaitu perlindungan hukum preventif dan perlindungan hukum represif. Perlindungan hukum bagi nasabah kredit perbankan dari penyalahgunaan keadaaan dalam perjanjian baku yang berbentuk preventif dalam Undang-Undang Nomor 8 Tahun 1999 Tentang Perlindungan Konsumen terdapat dalam Pasal 18 Ayat (1) Huruf g dan huruf $h$, yang mengatur pembatasan penggunaan klausul baku dalam perjanjian kredit. Regulasi tersebut bertujuan untuk mencegah terjadinya pemasalahan yang terkait dengan perjanjian kredit.

Sedangkan perlindungan hukum bagi nasabah kredit perbankan dari penyalahgunaan keadaaan dalam perjanjian baku yang berbentuk represif dalam Undang-Undang Nomor 8 Tahun 1999 Tentang Perlindungan Konsumen terdapat dalam Pasal 18 Ayat (3 dan 4), dan Pasal 62 Ayat (1). Penyelesaian sengketa yang timbul dalam hal ini dapat diselesaikan melalui penyelesaian sengketa konsumen secara litigasi yang merupakan penyelesaian sengketa melalui pengadilan dan penyelesaian sengketa konsumen secara non litigasi yang merupakan penyelesaian sengketa di luar pengadilan yakni dengan bentuk-bentuk sebagaimana yang diatur dalam Pasal 52 huruf (a) Undang-Undang Perlindungan Konsumen yang terdiri dari : arbitrse, konsiliasi, dan mediasi. Penyelesaian secara non litigasi atau penyelesaian sengketa di luar pengadilan ini dilakukan oleh Badan Penyelesaian Sengketa Konsumen (BPSK).

Adanya perlindungan hukum bagi debitur selaku konsumen di bidang perbankan menjadi urgen, karena secara faktual kedudukan antara para pihak seringkali tidak seimbang. Adanya kondisi demikian, melatar belakangi substansi Undang-Undang No. 8 Tahun 1999 Tentang Perlindungan Konsumen untuk memberikan pengaturan mengenai ketentuan pencantuman klausula baku antara lain: pelaku usaha dilarang mencantumkan klausula baku yang letak atau bentuknya sulit terlihat atau tidak dapat dibaca secara jelas atau yang pengungkapannya sulit dimengerti, pelaku usaha dilarang membuat atau mencantumkan klausula baku pada setiap dokumen dan/atau perjanjian yang menyatakan pengalihan tanggungjawab pelaku usaha, serta hal-hal lain yang merugikan debitur.

Walaupun ketentuan mengenai klausula baku sudah diatur dalam Undang-Undang No.8 Tahun 1999 Tentang Perlindungan Konsumen, akan tetapi pada kenyataannya seringkali masih terjadi pelanggaran sehingga akan merugikan kepentingan nasabah. Hal-hal yang harus diperhatikan oleh pihak bank untuk menghilangkan atau paling tidak meminimalisir terjadinya kerugian bagi nasabah karena memang harus dalam bentuk perjanjian baku, antara lain adalah sebagai berikut, (Johannes Ibrahim, 2004:49) :

1. Memberikan peringatan secukupnya kepada para nasabahnya akan adanya dan berlakunya klausula-klausula penting dalam perjanjian.

2. Pemberitahuan dilakukan sebelum atau pada saat penandatanganan perjanjian kredit/pembiayaan.

3. Dirumuskan dalam kata-kata dan kalimat yang jelas.

4. Memberikan kesempatan yang cukup bagi debitur untuk mengetahui isi perjanjian.

Dengan kerjasama yang baik antara pihak bank dengan nasabah, khususnya dalam hal adanya perjanjian baku mengenai kredit atau pembiayaan, serta pembukaan rekening di bank maka diharapkan akan lebih mengoptimalkan perlindungan hukum bagi nasabah, sehingga dapat meminimalisir dispute yang berkepanjangan di kemudian hari.

Perlindungan hukum kepada konsumen diarahkan untuk mencapai tujuan perlindungan hukum bagi konsumen, yaitu:

1. Meningkatkan kesadaran, kemampuan dan kemandirian konsumen untuk melindungi diri.

2. Mengangkat harkat dan martabat konsumen dengan cara menghindarkannya dari akses negative pemakaian barang dan/ atau jasa. 
3. Meningkatkan

pemberdayaan konsumen dalam memilih, menetukan, dan menuntut hak-haknya sebagai konsumen.

4. Menciptakan sistem perlindungan konsumen yang mengandung unsure kepastian hukum dan keterbukaan informasi serta akses untuk mendapatkan informasi.

5. Menumbuhkan kesadaran pelaku usaha mengenai pentingnya perlindungan hukum bagi konsumen, sehingga tumbuh sikap yang jujur dan bertanggungjawab dalam berusaha.

6. Meningkatkan kuliatas barang dan/ atau jasa yang menjamin kelangsungan usaha produksi barang dan/ atau jasa, kesehatan, kenyamanan, keamanan, dan keselamatan konsumen.

Perlindungan hukum bagi debitur dalam pelaksanaan perjanjian kredit ditinjau dari Undang-Undang Perlindungan Konsumen terletak pada adanya kewajiban bagi pihak bank untuk mengindahkan tata cara pembuatan klausula baku baik bentuk maupun substansinya dalam hal pembuatan perjanjian kredit untuk melindungi kepentingan-kepentingan debitur.

\section{PENUTUP}

\section{Kesimpulan}

Akibat hukum perjanjian baku bagi debitur dalam pelaksanaan perjanjian kredit perbankan yaitu debitur harus tunduk pada syarat-syarat dan ketentuanketentuan dalam perjanjian yang telah dibakukan sepihak oleh bank tanpa adanya kesepakatan diantara para pihak mengenai kredit dan aturan-aturan kreditnya.

Perlindungan hukum bagi debitur dalam pelaksanaan perjanjian kredit perbankan ditinjau dari Undang-Undang Perlindungan Konsumen terletak pada adanya kewajiban bagi pihak bank untuk mengindahkan tata cara pembuatan klausula baku baik bentuk maupun substansinya dalam hal pembuatan perjanjian kredit/pembiayaan untuk melindungi kepentingan-kepentingan debitur.

\section{Saran}

Pihak perbankan yang memiliki kedudukan kuat pada saat pembuatan kontrak baku prjanjian kredit hendaknya senantiasa memperhatikan aspek-aspek kepatutan dan keadilan sehingga saling masing-masing pihak sama-sama memperoleh kemanfaatan yang seimbang, untuk memberikan pihak sama-sama memperoleh kemanfaatan yang seimbang.

Bagi para nasabah khususnya nasabah kredit, untuk lebih cermat dan teliti dalam memahami dan mengerti isi perjanjian kredit dari pihak bank untuk menghindari adanya klausula baku yang memberatkan atau merugikan pihak nasabah sendiri.

\section{DAFTAR PUSTAKA}

Agus Yudha Hernoko, Hukum Perjanjian: Asas Proposionalitas dalam Kontrak Komersial, Kencana Prenada Media Group, Jakarta, 2013.

Janus Sidabalok, Hukum Perlindungan Konsumen di Indonesia, Citra Aditya Bakti, Bandung, 2006.

Johanne Daeng Naja, Pengantar Hukum Bisnis Indonesia, Pustaka Yustisia, Yogyakarta, 2009.

Johannes Ibrahim, Cross Default dan Cross Collateral Sebagai Upaya Penyelesaian Kredit Bermasalah, PT. Revika Aditama, Bandung, 2004.

Kartini Muljadi dan Gunawan Widjaja, Perikatan Yang Dilahirkan Dari Perjanjian, Raja Grafindo Persada, Jakarta, 2003.

Kitab Undang-Undang Hukum Perdata (Burgelijk Wetboek), 1992, Terjemahan oleh Subekti R dan R. Tjitrosudibio, Pradnya Paramita, Jakarta.

Made Suryana dan Rina Suwasti. Perlindungan Konsumen Ditinjau Dari Perjanjian Baku GaneC Swara.Vol. 3 No.2 September 2009.

Minatul Lusfida, Perlindungan Hukum Oleh Bank Kepada Pengguna Kartu Kredit (Credit Card Holder) Yang Mengalami Kerugian (Studi Di PT Bank Central Asia Tbk Cabang Pasuruan), Skripsi Malang, Fakultas Hukum Universitas Brawijaya, 2008. 
Muhammad, Abdulkadir. Hukum Perdata Indonesia, Bandung, Citra Aditya Bakti, 2010.

Philipus M. Hadjon, Perlindungan Hukum Bagi Rakyat Indonesia,Bina Ilmu, Surabaya, 1987.

Prihatin Effendi, Kedudukan Para Pihak Dalam Perjanjian Satandar Perbankan Ditinjau Dari Kitab Undang-Undang Hukum Perdata Dan Undang-Undang Nomor 8 Tahun 1999 Tentang Perlindungan Konsumen Jurnal Pro Hukum, Vol. IV, No. 2, Desember 2015.

Soedjono Dirdjosisworo, Pengantar Ilmu Hukum, Rajawal, Jakarta, 2012.

Soerjono Soekanto, Penelitian Hukum Normatif, Suatu Tinjauan Singkat, PT. Raja Grafindo Persada, Jakarta, 2007.

Supramono, Gatot, Perbankan dan Masalah Kredit Suatu Tinjauan di
Bidang Yuridis, Rineka Cipta, Jakarta, 2009.

Undang-Undang Republik Indonesia Nomor 10 Tahun 1998 tentang Perubahan Atas Undang-Undang Nomor 7 Tahun 1992 tentang Perbankan

Undang-Undang Republik Indonesia Nomor 8 Tahun 1999 tentang Perlindungan Konsumen, Lembaran Negara Republik Indonesia Tahun 1999 Nomor 42, Tambahan Lembaran Negara Republik Indonesia Nomor 3821.

Zulham. Hukum Perlindungan Konsumen, Kencana Prenada Media Group, Jakarta, 2013. 